\title{
URBAN AGRICULTURE AS THE PATH TO SUSTAINABLE CITY DEVELOPMENT. INSIGHTS INTO ALLOTMENT GARDENS IN ANDALUSIA
}

\author{
Barbara Maćkiewicz ${ }^{1}$, Raúl Puente Asuero², Antonio Garrido Almonacid ${ }^{3}$ \\ ${ }^{1}$ Institute of Socio-Economic Geography and Spatial Management, Faculty of Geographical and Geological \\ Sciences, Adam Mickiewicz University, Poznań, Poland \\ ${ }^{2}$ Department of Geography, History and Philosophy, Pablo de Olavide University, Seville, Spain \\ ${ }^{3}$ Department of Cartographic, Geodetic and Photogrammetric Engineering University of Jaén, Jaén, Spain
}

Manuscript received: February 1, 2019

Revised version: April 11, 2019

\begin{abstract}
MaćKiewicz B., Asuero R.P., Almonacid A.G., 2019. Urban agriculture as the path to sustainable city development. Insights into allotment gardens in Andalusia. Quaestiones Geographicae 38(2), Bogucki Wydawnictwo Naukowe, Poznań, pp. 121-136. 1 table, 8 figs, 6 pictures.
\end{abstract}

AвSTRACT: Increasing demand for urban agriculture (UA) can be perceived as a global phenomenon. In some parts of the world its main function is to feed the rapidly growing population while in others it is more associated with lifestyle and environmental issues. Undeniably, UA provides opportunities for sustainable city development. UA can support all pillars of sustainable development: ecological, economic, and social. However, depending on existing circumstances certain pillars may be influenced more than others. In this paper we concentrate on urban allotments in Andalusia and take Baeza as an example of a city with an interesting approach to urban gardening. We attempt to answer the question how urban allotments in Baeza affect the city's sustainable development and what remains to be done to make this influence more effective. Our study showed that allotment gardens in Baeza endorsed all three pillars of sustainable city development. However, developing broader community relations on the city scale, revival of declining local grocery market and dissemination of environmental initiatives which allotment gardens may also promote and facilitate was missing.

KEY WORDS: urban agriculture, sustainable development, allotment gardens, Andalusia, Spain

Corresponding author: Barbara Maćkiewicz, Institute of Socio-Economic Geography and Spatial Management, Adam Mickiewicz University, Poznań, ul. B. Krygowskiego 10, 61-680 Poznań, Poland; e-mail: basic@amu.edu.pl

\section{Introduction}

Increasing demand for urban agriculture (UA) can be perceived as a global phenomenon. In some parts of the world its main function is to feed the rapidly growing population while in others it is more associated with lifestyle (McClintock 2010; Tornaghi 2017; Van Tuij et al. 2018). It is assumed that throughout the world UA provides opportunities for sustainable city development. Urban agriculture is seen as support for all pillars of sustainable city development: ecological, economic, and social. However, just like in the case of sustainable development, in general it is difficult to balance the various pillars of sustainable city development by means of urban agriculture (Van Tuij et al. 2018). One can easily imagine that depending 
on existing circumstances certain pillars may be influenced more than others. So far the literature devoted to the topic has concentrated either on general theoretical reflections concerning the potential influence of urban agriculture on the sustainable city development (for instance Deelstra, Girardet 2000; Mougeot 2006; Pearson et al 2010; Hodgson et al. 201; Opitz et al. 2016; McClintock 2018; Van Tuij et al. 2018 ) or empirical studies related usually to only one selected aspect of the relationship between urban agriculture and sustainable city development (Smit et al.1996; Anthopoulou 2012; Wiskerke, Viljoen 2012; Segrelles 2015; Walker 2016; Purcell et al. 2018). There is a need for such studies which would evaluate in a practical but also critical way the contribution of urban agriculture to the all pillars of sustainable city development. Our article aims to fill this gap at least to some extent. First, basing of theoretical foundation proposed by Mougeot (2000) and Van Tuij et al. (2018) the significance of urban agriculture in the context of sustainable development of the city is presented. Secondly, on the basis of Peterson et al. (2010) and Deelstra, Girardet (2000) these aspects of urban agriculture which influence sustainable city development in a positive way are singled out. As a next step, the city of Baeza located in Andalusia has been chosen as a case study. It serves to assess the influence of urban allotments on all the pillars of sustainable city development. Thanks to examining the subject matter of municipal documentation, interviews and visits in the urban allotments, it has been possible not only to identify the positive impact but also to determine which aspects could be improved in order to make the influence of urban allotments on sustainable development of Baeza more balanced and effective.

\section{Urban agriculture and its contribution to sustainable development}

For centuries, the traditional model of compact, complex, efficient, socially cohesive city that was closely linked to the rural environment allowed preserving high levels of the environmental and territorial quality. In Europe, especially in the Mediterranean countries such as Spain, Italy or in the south of France, this model of compact city generated spaces of sociability, i.e. territories that favoured the meeting of economic activities and urban and peri-urban natural environments of certain value.

However, this model has changed radically since the second half of the 20th century, replaced by multiple urban forms that break the compact, multifunctional and even pragmatic character of the city. At the end of the 20th century new dispersed and fragmented urban realities were characterised by their extensive suburban peripheries of low density and predominant residential specialisation, industrial estates and large commercial enclaves strategically located at the intersections of expressways and motorways (Verdaguer Viana-Cárdenas 2013). As stated in the Andalusian Strategy for Urban Sustainability (Estrategia Andaluza de Sostenibilidad Urbana) (Junta de Andalucía 2011: 1) "The new city model bases its growth on a greater consumption of resources: soil, materials, water and energy. This is a trend that follows the path contrary to that of sustainability" As a result, currently, few cities in the world manage to obtain the balance between production and consumption and the inflows and outflows of natural resources.

Much of the sustainability problems of contemporary cities are due to uncontrolled extension of the urbanised areas to their immediate natural environment. This territorial expansion, lacking in planning or abusive to the land, results in haphazard formal and informal settlements. In the same vein, traffic and mobility are part of ecological problems which contemporary cities experience, being the main cause of the most conflictive aspects of the environment, such as excessive consumption of resources (energy, soil, etc.), and the impact on the urban environment (pollution, noise, local barriers to accessibility, insecurity, etc.). But the traffic problem is not just a local issue. This is a metropolitan, regional and even national problem to which solutions and executable actions of supra-local character must be sought. The effects of the abusive use of the private vehicle have negative consequences both for the historical and artistic heritage as well as the biodiversity of the cities, the socio-economic relations and the health of the population.

In the specific case of Spain, after the "chaotic planning" ("borrachera urbanística") of the last decade little, if anything, resisted the "power of 


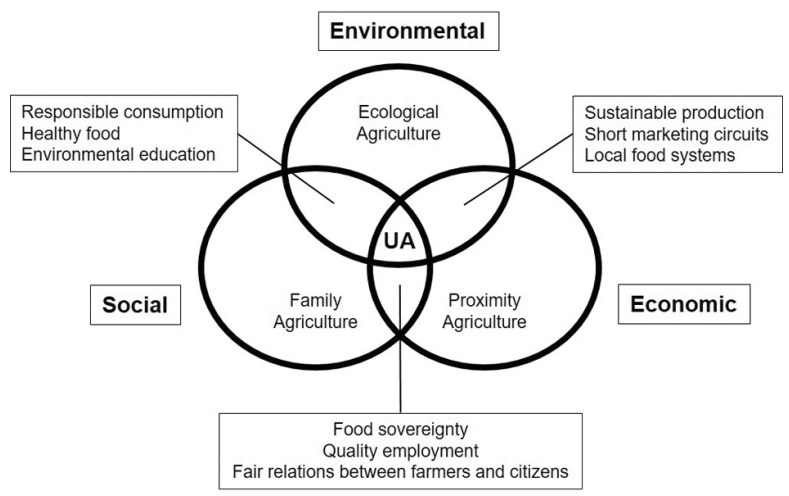

Fig.1. The significance of agriculture in the context of sustainable development of the city.

Source: own compilation.

brick and car", as a result forming abused landscapes of new urbanisations that underestimate rural and natural heritage as well as primary activities such as agriculture.

However, in order to stop the unsustainability of the contemporary city, there are many initiatives of national, regional and local governments all over the world. These projects focus on the fight against urban abuses, traffic control, waste management, sanitation, water purification, etc. Among these activities what stands out is the configuration of a network or green matrix in the interior and on the periphery of cities. The rebalancing of urban systems based on a network of green spaces composed of rings and vegetable corridors around urban centres which in such a way link and meld agricultural and forestry areas with citizens and neighbourhoods. Within this network or green matrix, urban and peri-urban agriculture plays an important role as one of the most important strategies to move towards urban sustainability (Fig. 1). Renowned researchers like
Luc Mougeot (2000) imagine the city of the future as a resilient and self-sufficient city that reaches the "ecosystem" stage through a commitment to urban agriculture.

From the point of view of governments, cities that develop new dynamics of land use, transformation of urban spaces and promotion of innovative activities, such as urban and peri-urban agriculture, become cities of high economic, social and environmental competences (Mougeot 2005, 2006; Puente 2010). For this reason, it is important to include both urban and peri-urban agriculture in the urban-regional legislation and in spatial development plans as well as in the economic and social development policies. As was already mentioned it is particularly important to take into consideration the potential contributions of urban agriculture to the different pillars of sustainable city development (Van Tuij et al. 2018). Hence, urban agriculture can positively affect all these pillars (Fig. 2).

Urban agriculture can help social development by offering urban food security, provision of healthy diet (access to fresh and healthy food), personal well-being (agricultural activity reduces health problems, physical, intellectual and psychological benefits can occur from direct involvement in UA), community building (promoting integration and participation), personal skills (e.g. horticultural and communication skills), sense of place (preserving national rural image, environmental values associated with person's place experience) (Deelstra, Girardet 2000; Peterson et al. 2010; Van Tuij et al. 2018). As for economic development, urban agriculture offers potential for using the land productively, providing self-supply, generating employment and income, saving

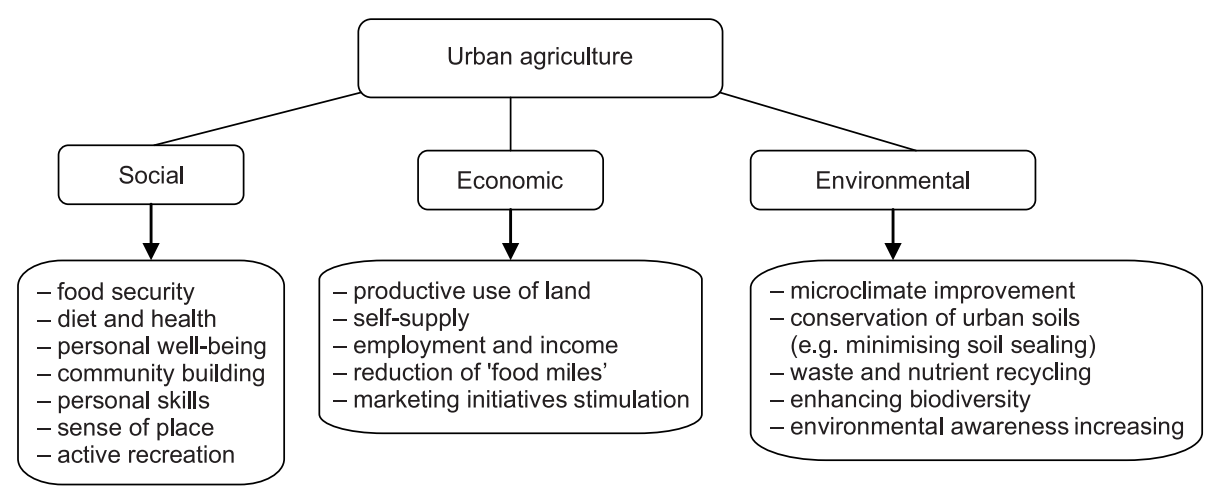

Fig. 2. Positive aspects of urban agriculture to sustainable city development. Source: own compilation on the basis of Peterson et al. 2010 and Deelstra and Girardet 2000. 
time and money (reduction of 'food miles'), stimulating marketing initiatives (Peterson et al. 2010; Segrelles 2015). From the environmental perspective, urban agriculture allows for the conservation of urban soil, microclimate improvement, pollution reduction (waste and nutrient recycling), biodiversity enhancement, and an increase in environmental awareness (Deelstra, Girardet 2000; Peterson et al. 2010; Puente 2012b).

\section{Development of allotment gardens in Andalusia}

Urban agriculture in Andalusia is not a novelty, as can be testified by its long history and rich agricultural, cultural and gastronomic heritage that exists in every part of the region. However, traditional agriculture has little or nothing to do with the allotment gardens that appeared in Andalusia in the 1990s and on a massive scale from the year 2008. The socio-economic crisis of 2008 that strongly affected Spain caused a reaction in the form of an agro-urban boom throughout the Spanish and Andalusian region
(Turmo 2013; Puente 2014; Camps-Calvet et al. 2015; Fernández Casadevante Kois, Morán 2015; Pourias 2015; Seguí 2017).

The beginning of contemporary allotment gardens in Andalusia took place in 1991 with the creation of the Miraflores's Park garden (huerto del Parque de Miraflores); a pioneering Spanish initiative of the neighbourhood association, "ProPark Educative Committee Miraflores" (Comité Pro-Parque Educativo Miraflores) that managed to turn an old waste dump into a park and an allotment garden. After this, three more urban gardens were created in Seville, i.e. the St Geronimo allotment garden (huerto San Jerónimo), the Rey Moro community garden (huerto del Rey Moro) and the Tamarguillo allotment garden (huerto Tamarguillo). All of them characterised the citizens' initiative of reclaiming urban space (Puente 2012a). During the 1990s few urban gardens were founded in Andalusia and they responded to a similar model: citizens' initiative of environmentalist groups. The main motivation for setting them up was related to bringing ecological awareness to the population via the values offered by agriculture as opposed to the urban values imposed by the city.

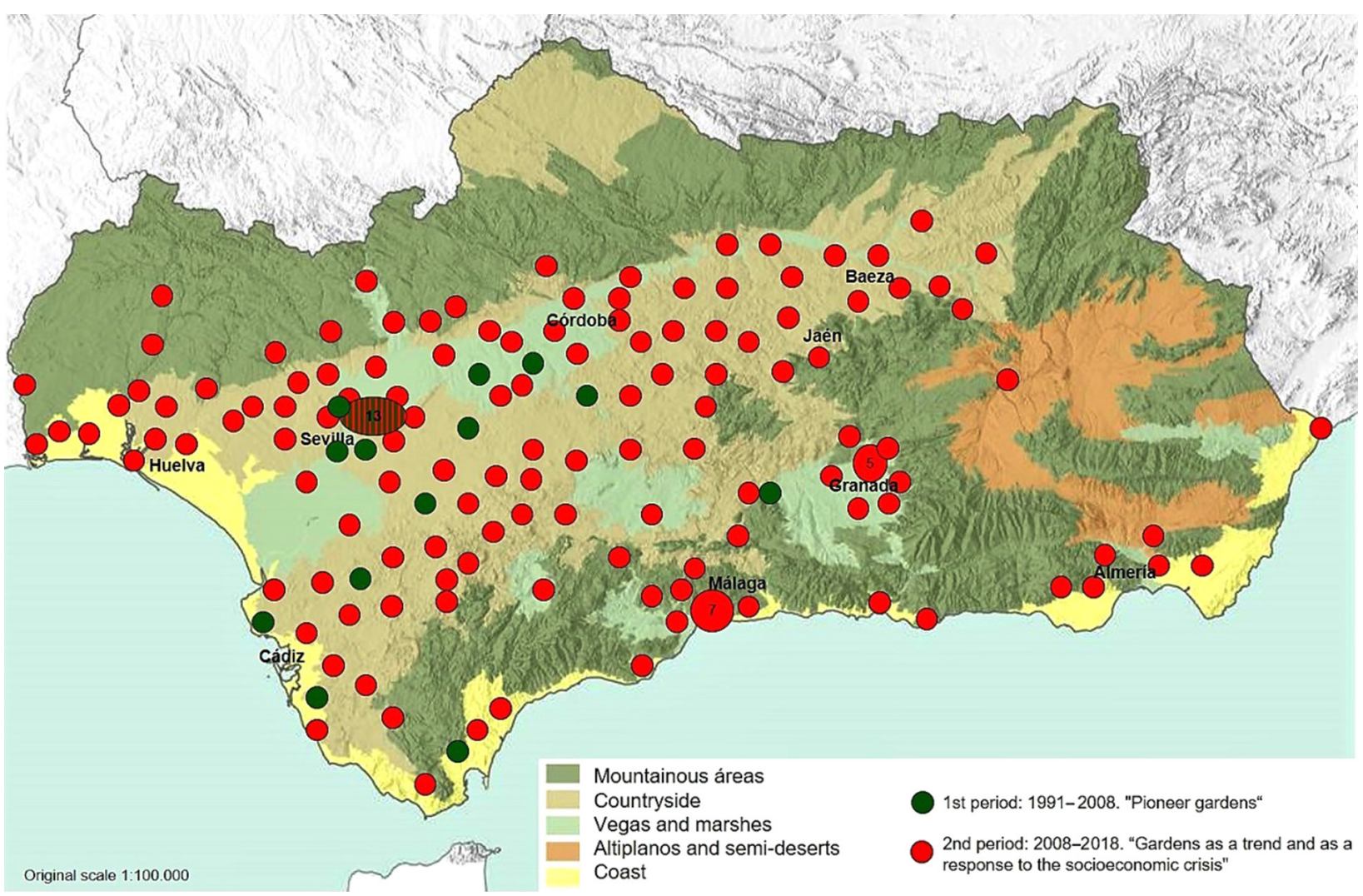

Fig. 3. Urban allotment projects in the region of Andalusia in the years 1991-2018. Source: own elaboration. 
During the first years of the 20th century, the citizen associations together with some city councils governed by progressive governments added a second motivation to the environmental motivations; that of encouraging the elderly to remain active. At that time various allotment gardens were created to respond to the demand of an increasingly aging but healthy population. During these years allotment gardens were developed to favour physical exercise, intergenerational relationships and the transmission of rural knowledge that had been acquired over a lifetime and that were gradually being lost.

From 1991 to 2008, 17 urban allotments were created in Andalusia, these were so-called "pioneer gardens" that addressed environmental motivations or "active aging". However, from then on, the process of creation of allotment gardens accelerated rapidly. Thus, in 2018 there were already approximately 320 allotments (estimated data, own preparation) (Fig. 3); 5.3\% of them were created in the period 1991-2008, while in the years $2008-2018,94.7 \%$ of the allotment gardens that currently exist in Andalusia were established. These figures show that since 2008 there has been a remarkable agro-urban boom in Andalusia.

In addition to the causes previously mentioned, allotment gardens are, on the one hand, products of fashion, of a global trend which affects not only Spain but the whole world, associated with healthy life, healthy eating and vegan and vegetarian lifestyles (Morán 2011; Morán, Fernández Casadevante 2012; Puente 2016), and on the other hand, they are a reaction of Spanish society against the socio-economic crisis. Thus, some allotment gardens have been set up as a social resource for disadvantaged families. In recent years all of the above factors have merged and are complementary to each other (Puente 2013; Ballesteros et al. 2014; Puente R. 2015; Puente 2016). In addition, if the pioneering gardens were generally created by citizens' movements (neighbourhood associations, environmental associations, etc.), nowadays, due to their social, political and electoral success, a plethora of such projects has arisen initiated by public administration both at regional and local levels. At the regional level, these projects are coordinated by the Regional Government of Andalusia (Junta de Andalucía) and at the local level by town and city councils (Ayuntamientos). The local Agenda 21, developed between citizens and municipalities, have been a very effective instrument for the promotion of allotment gardens as they are considered multifunctional spaces that can help the sustainability of the city from different perspectives (social, economic, environmental, etc.).
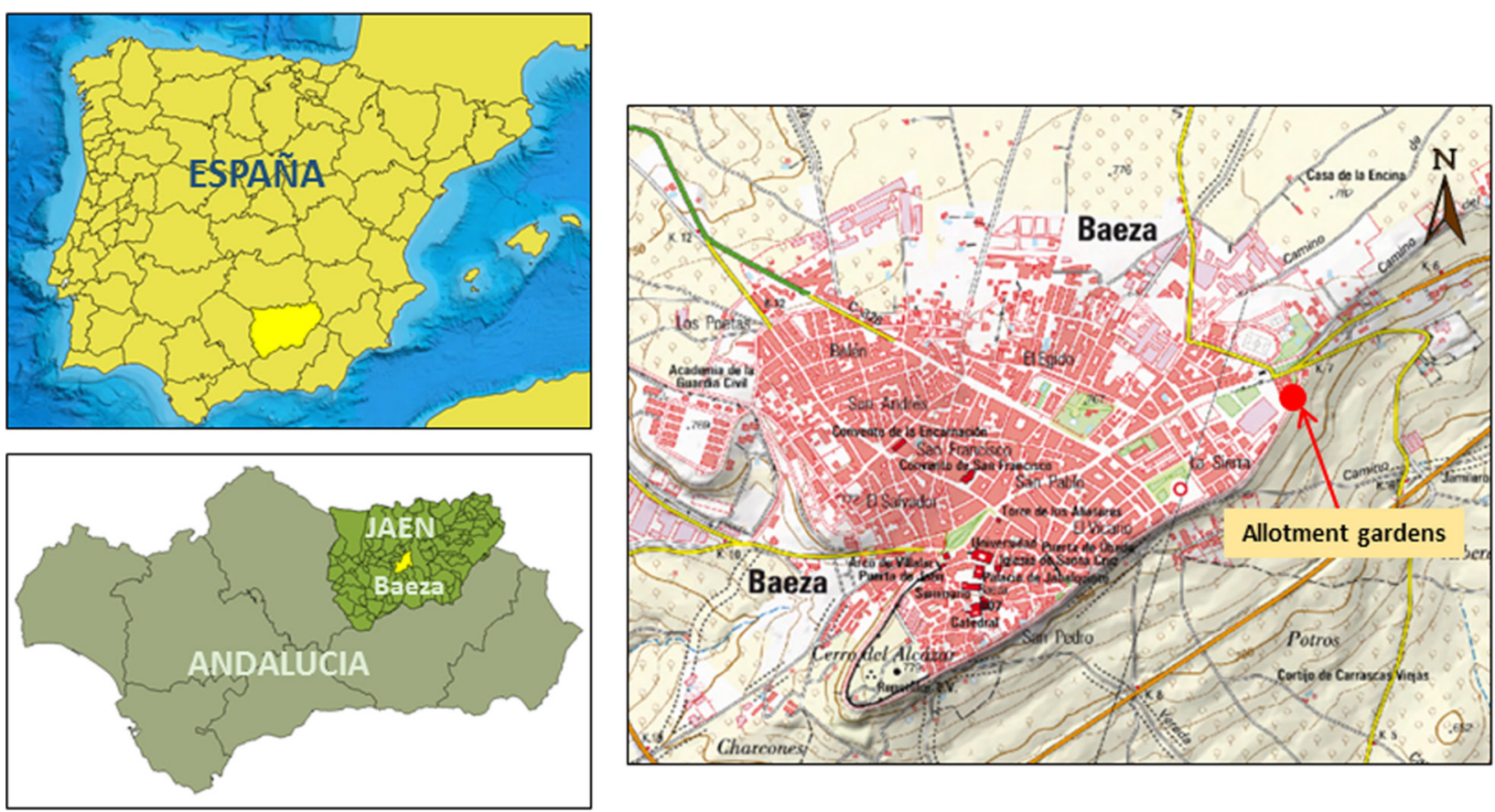

Fig. 4. The research area, its location from the perspective of the country, province and the city. Source: own elaboration. 
Regarding the distribution of allotment gardens in the region, it is noteworthy that the vast majority are located in towns and cities, valleys and countryside, as well as in the large cities of Andalusia (Fig. 4). The mountain areas have a lower number of allotments, since it is in the Guadalquivir Valley (Valle del Guadalquivir), the Mediterranean coastline and the provincial capitals that the majority of the Andalusian population is concentrated. It also seems to correspond to the different properties of the land in plains, valleys and countryside and mountain areas. Many citizens own a small piece of land in mountain areas while in fertile valleys and in the countryside citizens own no land since it is historically in the hands of the few. This seems to explain little interest of inhabitants and councils in creating allotment gardens for the citizens in mountain areas. Generally, the surface area of allotment gardens in Andalusia varies between $600 \mathrm{~m}^{2}$ and 4 ha. The size of each plot is very small compared to its European counterparts. The average size of a plot is $75 \mathrm{~m}^{2}$, although it can vary a lot among gardens. One can find plots ranging from $25 \mathrm{~m}^{2}$ to $400 \mathrm{~m}^{2}$.

To summarise, other interesting conclusions can be drawn about allotment gardens in Andalusia, for example the parallel, sometimes complementary and sometimes contradictory, process of the destruction of existing vegetable gardens (huertas) on the one hand, and "reinvention" of new agricultural land on the other (Calvo García-Tornel 1982; Calatayud 2005; Francés, Romero 2014; Melo 2018) (Picture 1). It is striking to see, on the one hand, new allotments appear on

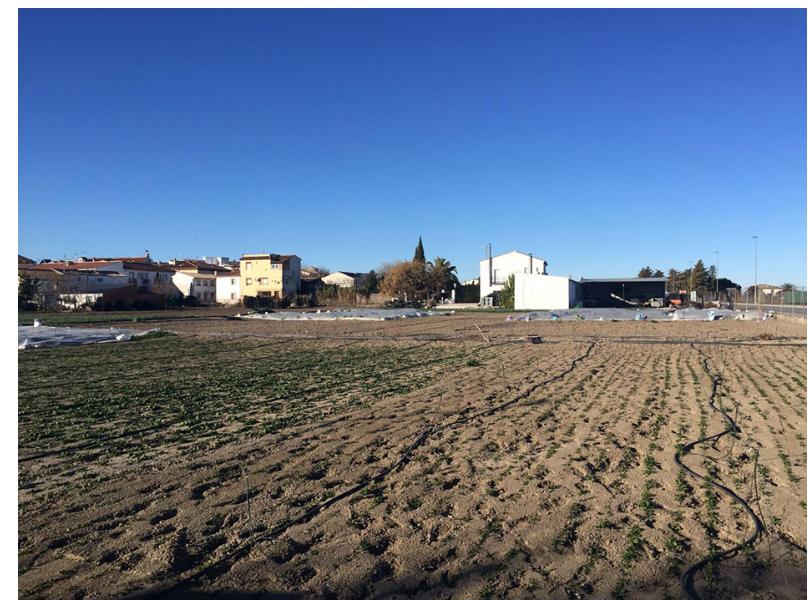

Picture 1. Traditional vegetable garden (huerta) in Baeza in 2018.

Source: picture taken by the authors. land without "an agricultural memory", and on the other, traditional vegetable gardens (huertas) with an existing agricultural footprint and high agronomic capacities disappear only a few meters away. Many urban environments in Andalusia still conserve agricultural spaces that must be protected and safeguarded so it would be sensible to use these land before inventing new locations.

\section{Study: Allotment gardens in Beaza}

\section{Methods}

Our study encompassed all publicly supported allotment gardens in Baeza (huertos municipales de Baeza) which were used at the time of our empirical research (from the spring of 2017 to the autumn of 2018). First, we gathered data, information and cartographic documentation on existing allotments (e.g. number, size, location, division, funding, goals, funding, objectives, crop requirements) on the basis of commune documentation and regulations. Second, we visited gardens, took documentary photos and conducted interviews with their users. The interviews were held in two stages, one was performed with the help of a questionnaire while the other was an open face-to-face conversation. They lasted between 30 and $60 \mathrm{~min}$ and concerned, among others, motivation for cultivating a plot, financial and professional situation of plot users, major benefits from a plot as well as crop types, their distribution and use. During the interviews the respondents were also asked to assess regulations related to the allocation of a plot. In total, 5 interviews were conducted and documented from March to June 2017. The following year in the autumn we returned to the allotment gardens and repeated the interviews with different users. In total, 4 interviews were held in November 2018. During that time we also talked to administrative and technical staff of the town hall responsible for the infrastructure, e.g. water supply to allotments as well as the functioning of the local grocery market (mercado de abastos de Baeza). Additionally, we met with a stallholder operating in the market. In these three conversations we asked about the creation of the project, the management of the allotments and possibilities to commercialise or promote allotment gardens' produce. 


\section{History, funding and governance of Baeza's allotments}

The first general declarations regarding the desire to create allotment gardens in Baeza appeared in the Municipal Action Plan of the Agenda 21 for Baeza (Plan de Acción Municipal de la Agenda 21 de Baeza) in June 2009. In that document the allotments were called social gardens (huertos sociales). In this context, and as part of the set of measures provided for in the above-mentioned Plan, there was a proposal for terracing the southern cornice of the city which was to be used for social gardens. These gardens were planned as a measure to improve the quality of life through sustainable city management and to preserve and improve the environment in Baeza. Essentially, the aim was to adapt several zones, divide them into plots of land ranging from 100 to $150 \mathrm{~m}^{2}$, and to offer them to pensioners in order to carry out activities related to the environment. Nevertheless, it was only four years later that the project began to be implemented. At the beginning of 2013, the area of $14,959 \mathrm{~m}^{2}$ located on the Paseo de las Murallas, i.e. the stretch of land separating built-up and rustic part of the city, was chosen for the establishment of allotment gardens (Fig. 4).

In the spatial development plan POGU (Plan General de Ordenación Urbana) of 1997 as well as in the following plan of 2012, the zone in which the allotment gardens were prearranged was classified as the area where no development is allowed (no urbanizable). In the 1997 plan this area had a category of special protection with the reference to the southern cornice of the city. In the 2012 plan the land category was the same. However, the necessity to protect its remarkable landscape was even more emphasised by classifying it as an Area of Landscape Interest (Área de Interés Paisajístico). In other words, this is the area protected against the processes of devastation and devaluation of the landscape where construction as well as alteration is forbidden. Importantly, the compliance of the planned use of the area with the spatial development plan was confirmed by the report of the city architect ${ }^{1}$ which stated that

Baeza City Counci Architect's Report of 21 May 2013 (Informe de la Arquitecta del Excmo. Ayuntamiento de "agricultural land use with irrigation (huerta) is compatible with the character of the land, so there is no problem with the adaptation of the land to irrigated cultivation" (see the report of the city architect of May 2013). In short, the area enjoyed all the spatial planning guarantees necessary to implement the project of allotment gardens.

After designating the area and checking the conformity of its anticipated function with the local development plan (PGOU), the adaptation of the land began. For this purpose, EUR 27,000 was allocated and spent on three basic activities, i.e. supplying non-potable water to a nearby surface tank and then to the plots, adapting the cultivation area to the orography of the land and installing the irrigation system which delivers water to all plots ${ }^{2}$. In the meantime, the labelling of the allotments changed into ecological family gardens. On October 8, 2013 $3^{3}$, the legal basis for the transformation of land belonging to the city into municipal gardens (the name under which they are finally known) was approved. According to these regulations, gardens were to be granted for two years with a renewal clause not only to retirees but also to the unemployed. In addition, all these people had to be registered in Baeza (for more requirements see Table 1). By orgranising allotment gardens a double goal was sought. On the one hand, allotment gardens served a socio-economic function, because they were to improve unfavourable circumstances of the unemployed or to entertain people who have already completed their period of work, offering them free use of gardens, and on the other hand, they performed an environmental function as well, because an ecological production system was set up with a clear ban on using dangerous plant protection products and which guarantees respect for health and the environment.

It was also decided that each plot will have an area not smaller than $100 \mathrm{~m}^{2}$ and an 80-centimentre high separating fence. Eventually, 72 plots were made available to users (Fig. 5).

Baeza de 21 de Mayo de 2013).

2 Baeza 2011-2015 Management Exposition. Baeza City Council. (Baeza 2011-15. Memoria de gestión. Excmo. Ayuntamiento de Baeza).

3 Decree of the Mayor of Baeza of 8 October 2013 (Decreto de Alcaldía del Ayuntamiento de Baeza firmado el 8 de octubre de 2013). 
Table 1. Decalogue of mandatory rules regarding the use of allotment gardens in Baeza.

\begin{tabular}{|c|c|}
\hline 1. & $\begin{array}{l}\text { It is not allowed to change the layout of plots or combine them with neighbouring ones or close them with } \\
\text { permanent fences. }\end{array}$ \\
\hline 2. & The City Council provides water (non-potable). \\
\hline 3. & Each user must keep the plot in good condition and return it in an orderly and clean state. \\
\hline 4. & The plot user can obtain agricultural tools that should be returned when he/she no longer uses the plot. \\
\hline 5. & There is a yearly obligation to fertilise the plot at the appropriate time for this activity. \\
\hline 6. & The City Council may unilaterally cancel the use of the plot if public interest is threatened. \\
\hline 7. & The use of the plot is free of charge. One family unit has the right to one plot. \\
\hline 8. & The plot user should respect both other users and the municipal personnel. \\
\hline 9. & The City Council reserves the right to inspect plots to check whether their use is consistent with their purpose \\
\hline 10. & $\begin{array}{l}\text { The products obtained are intended for own consumption but they can also be sold on the municipal grocery } \\
\text { market on condition that an appropriate fee is paid. }\end{array}$ \\
\hline
\end{tabular}

Source: own compilation on the basis of Decreto de Alcaldía del Ayuntamiento de Baeza firmado el 8 de octubre de 2013.

In February $2014^{4}$, the first applications were submitted, and in April, 50 plots were given to users. However, not all plots found their users and, as a result, another application process started in March leading to the occupation of 18 more

4 Decree of the Mayor of Baeza of 6 March 2014 (Decreto de Alcaldia. Excmo. Ayuntamiento de Baeza. 6 de marzo de 2014). plots. Thus, despite the second application procedure, some plots were still left unoccupied.

"At first people did not have any idea what they could get. They thought that $100 \mathrm{~m}^{2}$ was not enough for cultivation. They believed that it was not worth the effort. They looked at is as if it was barren land which could not produce anything." (an interview with plot holder 6, a retiree, 2018)

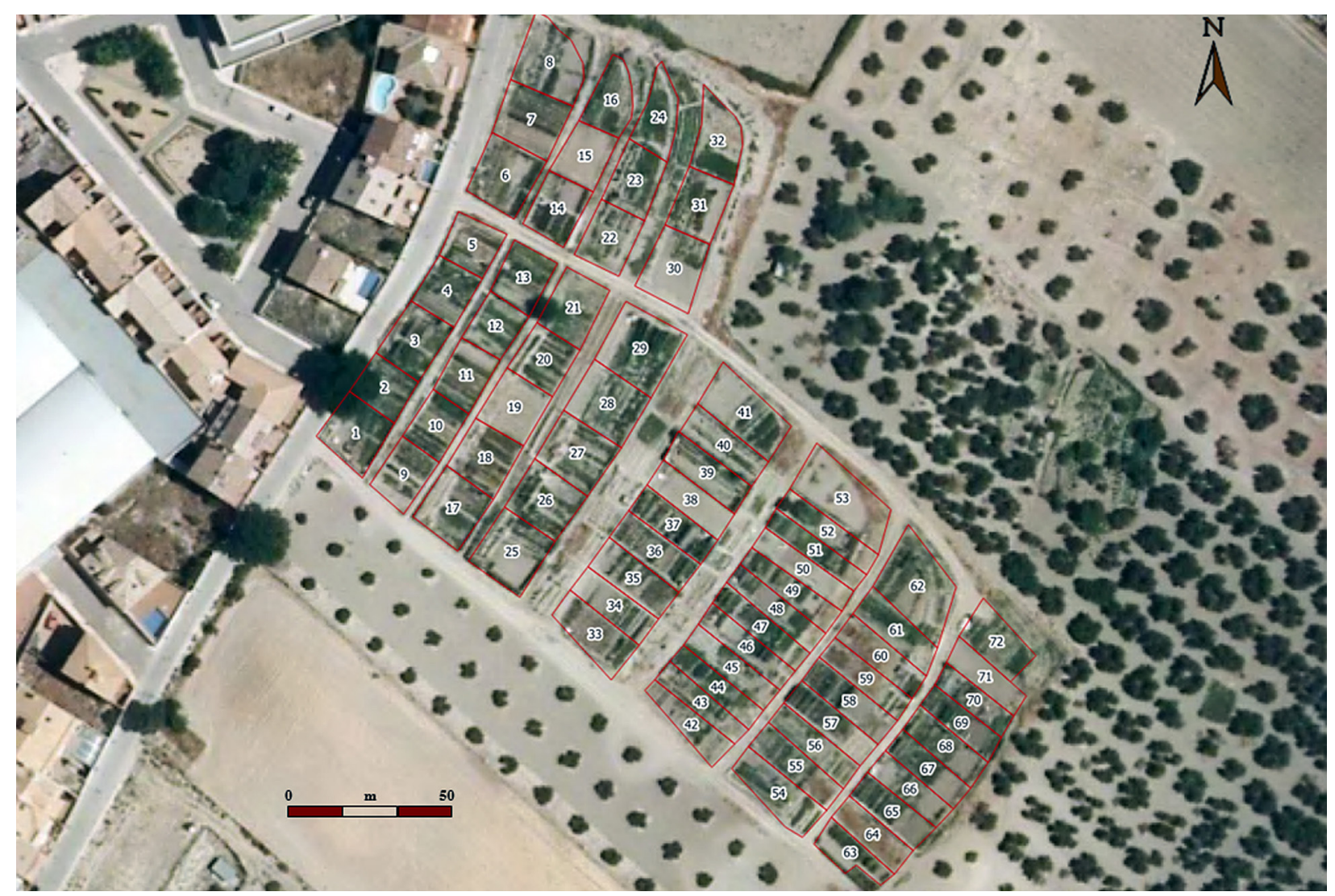

Fig. 5. Allotment gardens in Baeza in 2018. Source: own elaboration. 


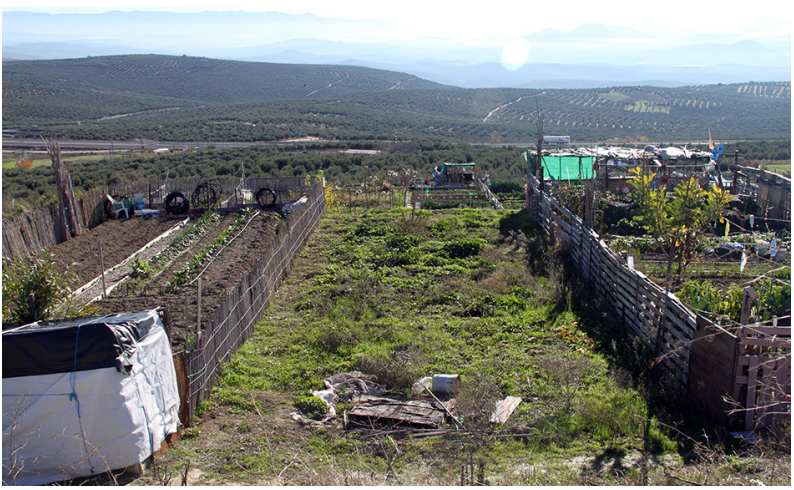

Picture 2. An example of a vacated plot. Source: pictures taken by the authors.

A few months later, in June $2014^{5}$, the City Council again announced a competition for granting the remaining 4 plots. Only then did the demand exceed the supply probably due to the already visible development of the first plots and the fact that some people remained on the waiting list.

At the end of November 2018 it was determined that in the group of plot holders slightly over half (42 people) cultivated their plots without interruption, cyclically renewing the contract, while the rest of the plots changed their users. In total, there were two cases of the violation of the right to use the plot because of non-compliance with the regulations ${ }^{6}$. At the end of 2018, two plots were vacated waiting for potential users and six more plots would be vacated soon as their holders announced that they would not renew the contract (Picture 2). As there was no waiting list at the time one can state that the number of plots is sufficient.

\section{Allotment gardens in Baeza - pillars of sustainable development}

\section{Social pillar}

Allotment gardens in Baeza were founded primarily with two social groups in mind, i.e. the

Decree of the Mayor of Baeza of 4 June 2014 (Decreto de Alcaldía. Excmo. Ayuntamiento de Baeza. 4 de junio de 2014).

6 Rural Guard Inspection records aimed at ensuring and guaranteeing compliance with the regulations of allotment garden use of 6/10/2015, 20/04/2016 and 14/10/2016. (Actas de inspección de la Guardería Rural al objeto de comprobar y garantizar el cumplimiento de las normas de funcionamiento de los Huertos Familiares de fechas 6/10/2015, 20/04/2016, y 14/10/2016).

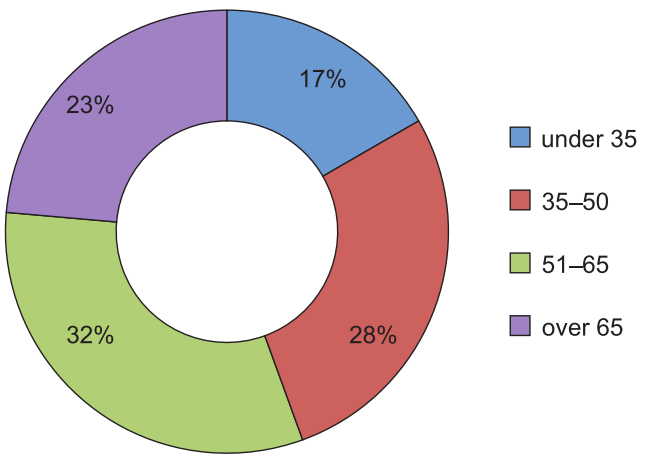

Fig. 6. Age structure of plots holders in 2014. Source: own elaboration based on data from the city office.

unemployed and retirees. This is evidenced in the age and economic structure of plots holders (Fig. $6,7)$. In 2014, the average age of plots users was 52. Among the first group of plot holders there were $12(16.7 \%)$ people aged under $35,20(27.8 \%)$ people aged between 35 and 50, 23 (31.9\%) people aged between 50 and 65 and 17 (23.6\%) over 65 years old. The typology of the first petitioners was as follows: the unemployed $18(25 \%)$, pensioners $6(8.3 \%)$, retirees $17(23.6 \%)$, and part time-workers or other people with low income resulting from, e.g. disability or maintaining large families 31 (43.1\%). In 2018, most plot users were at the retirement (30\%) and pre-retirement age $(28 \%) .42 \%$ of plot holders were people under 55, among whom $17 \%$ were younger than 40 . This means a relatively balanced age structure. In terms of their occupational situation, $40 \%$ were retired or were pensioners, and $60 \%$ were unemployed or have low income. Thus, the target groups of beneficiaries had an even share in the structure of allotment users.

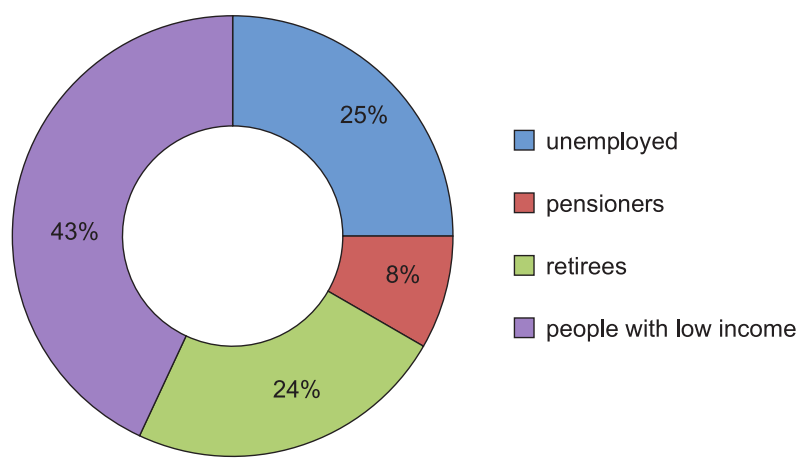

Fig. 7. Economic structure of plots holders in 2014. Source: own elaboration based on data from the city office. 
By pointing out positive social aspects of cultivating plots, their users strongly emphasised the possibility of maintaining a healthy diet thanks to access to quality organic products.

"The biggest benefit of the allotment is knowing that you are eating healthy products." (an interview with plot holder 2, a part-time worker, 2017)

Additionally, another key function of the plot was the possibility of active recreation and its contribution to personal well-being.

"It is a physical activity, other than just walking. I cultivate it purely for pleasure." (an interview with plot holder 6, a retiree, 2018)

"Main motivation for using the plot? To get ecological food for own consumption. To be busy, to have a place for exercising a bit. Keep your head and body active, stay in shape, good health, stay active." (an interview with plot holder 7, a pensioner, 2018)

Positive impact of the plot on the development of personal skills was stressed, especially by the elderly.

"You have to improve yourself, study, surf on the Internet, for example, "Toni's garden" website (La huertina de Toni." (an interview with plot holder 6, a retiree, 2018)

When asked about the influence of allotment gardens on community building, the interviewees claimed that the allotments contributed to the deepening of social ties, but only between the plot users. They emphasised that the plot holders helped each other and cooperated in harmony, also with the migrants cultivating the plot.

"There are two immigrants, one from Romania and the other from Peru. They get on well with the rest of the users. There are no conflicts. Besides, they cultivate their plots well." (an interview with plot holder 9, a pensioner, 2018)

At the same time, however, it was pointed out that there could be no question of community building between plot users and the other inhabitants of Baeza. It was even mentioned that from time to time the small neighbourhood conflicts between the allotment users and residents of nearby houses occurred.

"When the neighbours wash their cars they allow the dirty water to go to the allotment gardens. That is how conflicts start. Luckily, there are no big rows. Also the noise bothers all the neighbours. Machines are not allowed during bank holidays. You cannot disturb others." (an interview with plot holder 7, a pensioner, 2018)

"The smell, the noise, everything disturbs the neighbours." (an interview with plot holder 8 , a retiree, 2018)

For the plots users, an important issue was the lack of celebration acknowledged by the whole town, e.g. allotments' day, which would allow them to present themselves to the wider community.

"There is a need for some kind of allotment garden harvest festival which would allow plot users to present their produce and would be to get acknowledgement from the Baeza community." (an interview with plot holder 6, a retiree, 2018)

What was also mentioned was the absence of cooperation with schools, and thus, the lack of establishing intergenerational relations between allotment users and pupils. Additionally, there was also no form of collaboration between plot holders and professional horticulturalists from Baeza.

\section{Economic pillar}

In comparison with other allotment gardens existing in Spain, also in Andalusia, plots in Baeza were characterised by a large area (for more details see Puente 2011; Puente 2012a) (Fig. $8)$. In addition, the plots were made available to the users free of charge which is also not common. They paid neither for the allotment nor for the water used to irrigate it. The average plot size was $126.38 \mathrm{~m}^{2}$, which means that the plot size was double the median plot size for Andalusia (see page 126). The area ranged from $116.37 \mathrm{~m}^{2}$ for the smallest plot to $139.92 \mathrm{~m}^{2}$ of the plot with the largest area. The majority of plots (54\%) oscillated between 120 and $130 \mathrm{~m}^{2}$, five of them (7\%) 


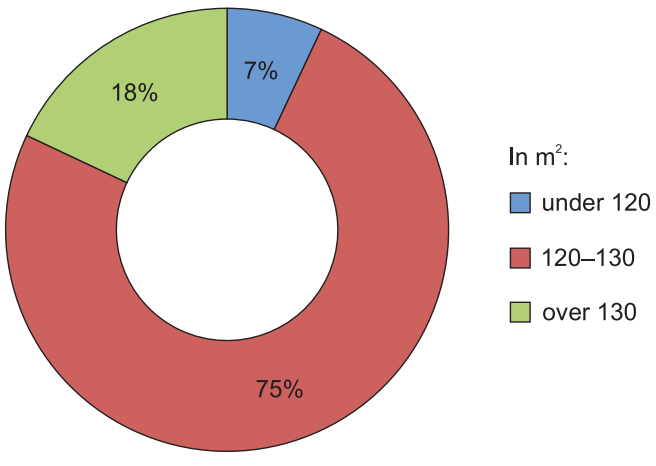

Fig. 8. Average plot size.

Source: own elaboration based on data from the city office.

had a smaller area and the size of the remaining thirteen $(18 \%)$ exceeded $130 \mathrm{~m}^{2}$. All interviewees stated that the plot area was adequate and sufficient. They claimed that the food they produced was used for self-supply and the remaining surplus was distributed among family members.

"We use the crops for our own consumption and give them to the family as well. We also process and preserve food." (an interview with plot holder 8 , a retiree, 2018)

The interviewees highlighted that the economic benefit of holding a plot was one of the most important advantages. They stressed the possibility of savings in the family budget, which automatically means increasing real income.

"In my case having the plot benefits my economy." (an interview with plot holder 1 , an unemployed, 2017)

However, they had a problem estimating the exact amount of financial profits and their own investments. Yet, they emphasised the importance and value of the quality of crops.
"What does it cost? The plants not that much. Time is the main expense." (an interview with plot holder 7, a pensioner, 2018)

"You know the value. The price is not known. But you see the product that satisfies you. You are satisfied with its quality." (an interview with plot holder 2, a part-time worker, 2017)

They also pointed out that the land is used productively throughout the year. That means that from the area which was once a wasteland, food is obtained several times a year (Picture 3). Locally obtained food reduced the cost of transport and 'food miles'.

"We use the plot throughout the year. Planting and harvesting all year round." (an interview with plot holder 8, a retiree, 2018)

Unlike the majority of Spanish, including Andalusian municipalities, where crops from urban allotments are intended only for own consumption, the city of Beaza has allowed their direct sale on the local grocery market (mercado de abastos) (Puente 2012a) (Table 1). Nevertheless, none of the plot users has taken advantage of this opportunity. Thus, the stimulation of marketing initiatives by urban allotments has not been put to use in Baeza so far.

"Nobody sells their crops in the grocery market." (an interview with plot holder 9, a pensioner, 2018)

It seems that the sale of crops or their preserves might not only improve the financial situation of plot holders, but also positively affects the revival of the local grocery market (Picture $4,5)$. However, as can be concluded from the
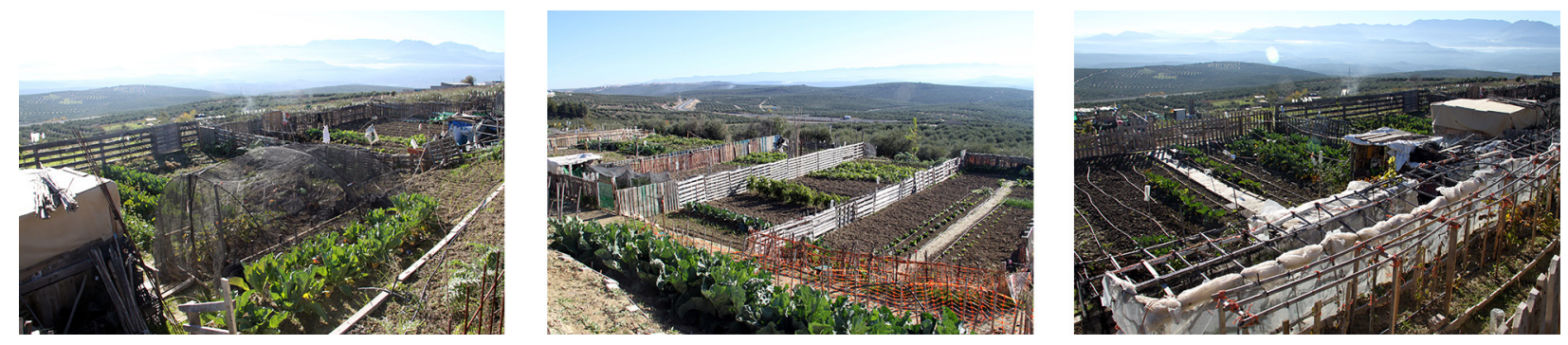

Picture 3. Allotment gardens in Baeza at the end of November 2018.

Source: pictures taken by the authors. 

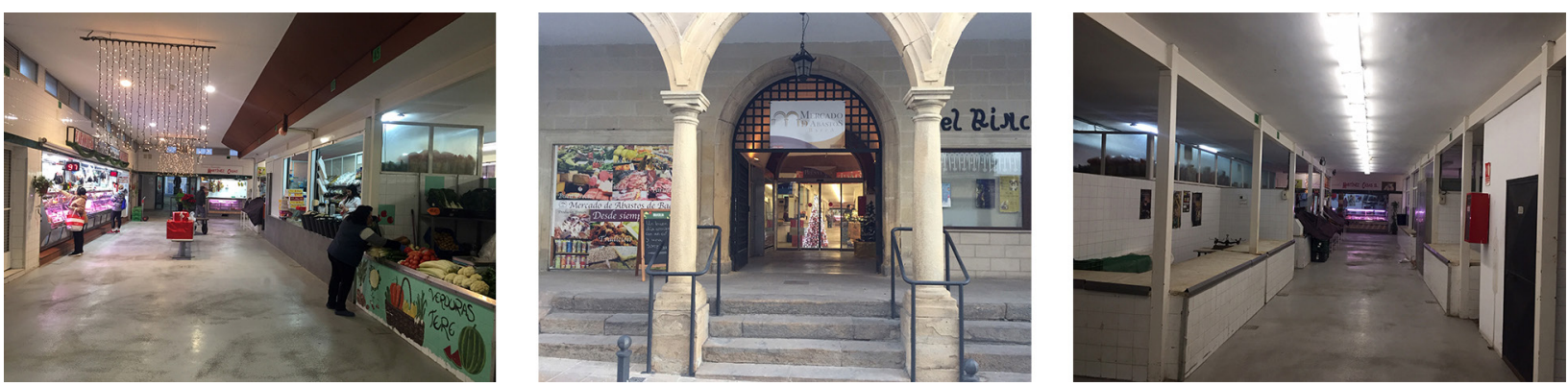

Picture 4. Local grocery market in Baeza in 2018.

Source: pictures taken by the authors.

interviews, the mere presence of plot users at the grocery market would probably not change its situation radically but could somehow be helpful to revive it.

"Nowadays the local grocery market in Baeza is in a very bad situation. There are many disused stalls because when the previous contractors retire or leave for any reason, nobody occupies them. At the moment there is no assigned stall for urban allotment users. However, there would be no problem if they wanted to sell there. As I say many of the stalls are unoccupied. It would be a good idea to organise some kind of fair for allotment produce a few times a year. Yes, that could be interesting but I do not think this would significantly improve the current condition of the market." (interlocutor 2, a person responsible for the grocery market on behalf of the town hall, 2018)

"I think some kind of fair of allotment garden crops may be interesting, but I do not think that it will change the present situation of the grocery market that much." (interlocutor 3, an entrepreneur functioning in the local grocery market, 2018)

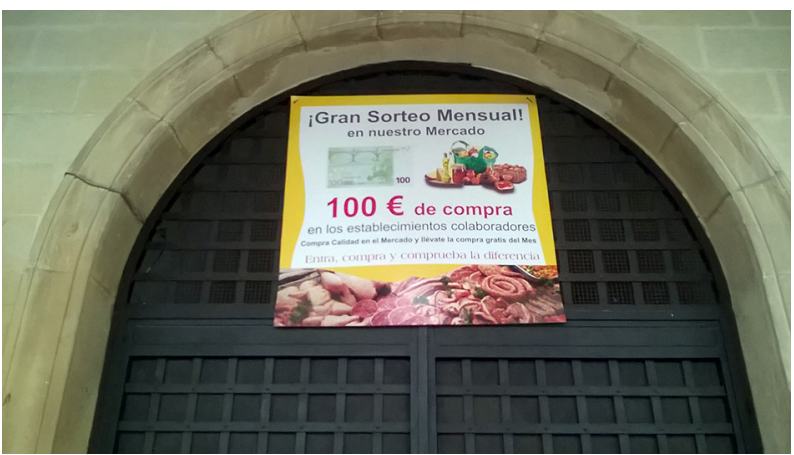

Picture 5. A monthly lottery aimed at stimulating trade at the market.

Source: picture taken by the authors.
Despite the existing possibility of selling crops at the local grocery market, nobody used that opportunity. Moreover, no fair of allotment products was held. Neither was any food sharing initiative organised whereby plot users could offer their products to the wider community of the city. Evidently, the establishment of allotments has in no way contributed to the revival of the declining local grocery market so far.

\section{Environmental pillar}

The area where the location of urban allotments was arranged had all the spatial planning guarantees necessary to put into action the project of allotment gardens. Agricultural land use with irrigation (huerta) was in accordance with the character of the land and protection requirements of the Area of Landscape Interest (Área de Interés Paisajístico). Therefore, it can be stated that the function of the area proposed by the city was well chosen with the aim of contributing to the protection of urban soil and the landscape. This protection was also guaranteed by the regulations requiring ecological agriculture and yearly obligation to fertilise the plot at the appropriate time for this activity. In addition, the observed practice of setting aside a certain proportion of the plot proves that the land was properly used and the soil protected (Picture 5).

"We let a part of the land rest. A piece of the plot is always left idle." (an interview with plot holder 6 , a retiree, 2018)

Distribution and water use management, especially after the introduction of the project "Urban allotments in Beaza: formation programme, study and efficient development of 


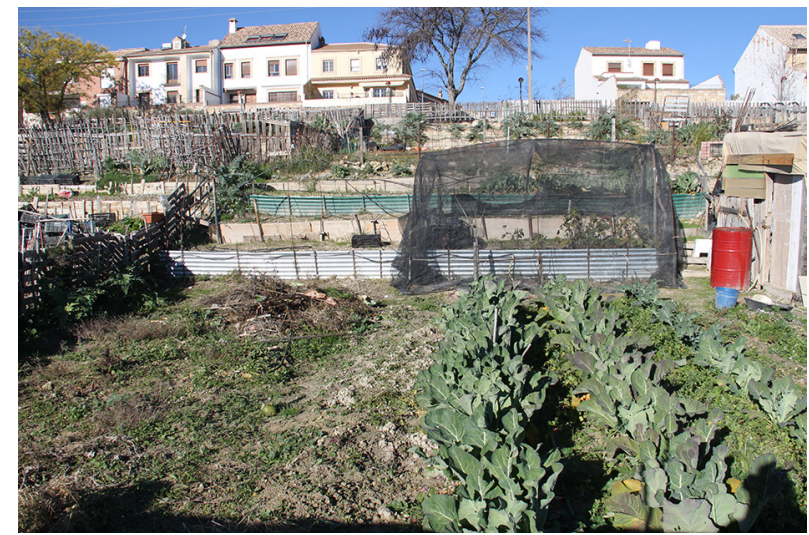

Picture 6. An example of setting aside (barbecho) a certain proportion of the plot.

Source: picture taken by the authors.

irrigation system and The Communication Plan", was also in line with the rational management of water resources.

"Non-potable water is delivered free of charge. So plot holders do not pay for it. Initially it was supplied twice a day, at present it is delivered only in the afternoon." (interlocutor 1, a town hall representative, 2018)

However, the issue of increasing environmental awareness and biodiversity was less optimistic. Few plot users (four people) provided the certificate of having participated in a "Horticulture and Floriculture" course organised for the unemployed by the Regional Government of Andalusia (Junta de Andalucía) The Advisory Council for Employment, Andalusian Employment Service of Jaén (Consejería de Empleo, Servicio Andaluz de Empleo de Jaén). The course lasted from May 10 to October 15, 2010 and covered 659 hours, including 240 theoretical, 360 practical and 59 complementary training. Since the beginning of the existence of allotment gardens in Baeza, the city together with the Regional Government of Andalusia (Junta de Andalucía) has organised only one training course for plot users. The course took place from April to August 2015 (325 hours, including 150 theoretical classes, 150 hours of professional practice and 25 hours of complementary training) and concerned ecological agriculture but was much shorter than the previous one. As the number of places in the course was limited, not all allotment holders participated in it. In this case, younger people, i.e. in the productive and pre-retirement age, were given priority. This proves that the majority of plot holders were self-reliant in gaining specialist knowledge. Unfortunately, the bank of autochthonous and ecological seeds has not been created in Baeza so far. What is more, there was no cooperation either with the Andalusian Seed Network ${ }^{7}$ (Red Andaluza de Semillas) or with the Germplasm Bank of Andalusia8 (Banco de Germoplasma de Andalucía). That is why, plot users expressed an urgent need to resolve this issue.

"We would like to have a seed classification centre as we would like to take advantage of it to work with our seeds" (an interview with plot holder 6, a retiree, 2018)

From the words of plot holders it can be inferred that they had an incorrect approach to using seeds. They wanted to use commercial seeds which are hybrid or sterile for reseeding. Clearly it did not work. Thus, one of the respondents came to a paradoxical conclusion.

"I buy the seeds because it is better when they come from another place" (an interview with plot user 7 , a pensioner, 2018)

The above-mentioned issues indicate that the actions of the city of Baeza to increase ecological awareness and enrich biodiversity were insufficient. The seeds are the beginning of everything, the principle of life and the principle of the urban garden, that is why it is so important to use seeds of good quality and adapted to the environment in which they are going to be used. The gardeners can gradually create their own bank of native seeds and for this, at the end of the harvest, they should save the best seeds that will serve for future crops. Allotment gardens should not be understood only as agricultural spaces, they are also receptors and disseminators of environmental initiatives - receptors because it is necessary to

In Andalusia there exists the Andalusian Seed Network (RAS Red Andaluza de Semillas), which functions as a bank of indigenous and ecological seeds that is based on the exchange of seeds between farmers. They do not sell or buy seeds, they only exchange them. It is a non-governmental association.

8 The Germplasm Bank of Andalusia in Córdoba is an organisation of the Junta de Andalucía. 
learn and make a correct use of water, of land, of phytosanitary products, etc., and disseminators of environmental awareness because the example of urban gardens can be shown to schoolchildren in the municipality and even to other farmers.

\section{Conclusions}

The agro-urban boom which can be observed around the Andalusia grants a new dimension of empowerment to citizens and a potential intervention strategy for administrations. The proliferation of urban gardens and other types of urban agriculture should be considered almost as acupuncture interventions in the city which influence its social and environmental sphere (Maćkiewicz et al. 2018). Faced with the "non-places" of the postmodern city, the allotment gardens are landscapes that, little by little, without fuss, are becoming an objective and subjective, and also symbolic reality of cities. Likewise, in the face of stressful landscapes and the speed of daily life noticeable in the media and in digital relationships, urban allotments are "slow spaces", places of slow rhythm where the cycles of life influence the relationships among citizens and those with the city. It is often stressed that urban agriculture can support all pillars of sustainable development of a city: ecological, economic, and social (Deelstra, Girardet 2000; Pearson et al. 2010; Fernández, Morán 2012; Van Tuij et al. 2018). However, balancing the various pillars of sustainable city development by means of urban agriculture is a challenge (Van Tuij et al. 2018). Depending on implemented policies and existing circumstances certain pillars may be influenced more than the others. As a result, the potential of urban agriculture is not fully used. One of the reasons why it happens is the fact that local authorities do not have enough information and experience necessary to implement systemic and effective solutions in this area. Using Baeza as a case study, this paper sought to answer the question how an UA initiative - urban allotments, affects the city's sustainable development and how to make this influence more effective.

The study conducted proved that establishing allotment gardens in Baeza endorsed all three pillars of sustainable city development. In the case of the social pillar urban allotments had a positive impact on the situation of social groups they were designed for, namely the unemployed, people with low income and retirees. Allotments increased their food security, improved their diet, health and personal well-being. They also enriched their personal skills and allowed active recreation. However, as for community building, the significance of allotment gardens was not as far-reaching. The only visible effect was the cooperation between the plot users and it did not affect the relations between plot holders and the rest of Baeza inhabitants. There was no cooperation with schools, and thus, no intergenerational relations between allotment users and pupils were established. Additionally, there was no form of collaboration between plot holders and other inhabitants of the city including professional horticulturalists. In other words, gardens were not used to instil a sense of place for children or any other group. Thus, the potential of allotment gardens to create broader community relations on the city scale was not fulfilled.

Considering the economic pillar, allotment gardens in Baeza allowed the effective use of a former wasteland throughout the year. They also provided food for their users and their families and, what follows, made it possible to make some savings in the family budget. Locally obtained food reduced the cost of transport and 'food miles'. However, plot holders did not undertake marketing initiatives. Despite the existing possibility of selling crops at the local grocery market nobody used that option. Moreover, no fair of allotment products was held. Neither was any food sharing initiative organised whereby plot users could offer their products to the wider community of the city. Clearly, the establishment of allotments has in no way contributed to the revival of the declining local grocery market so far.

As far as the environmental pillar is concerned the creation of allotment gardens helped in soil and landscape conservation. It also had an influence on more conscious water management by plot users. However, the research findings indicate that the actions of the city of Baeza to increase ecological awareness and enrich biodiversity were insufficient. Few plot holders participated in professional training concerning ecological agriculture. Apart from the training courses in 2010 and 2015, no other course was organised. No complementary activities were available, nor was 
there any possibility of obtaining professional assistance. As a result, the majority of plot holders were self-reliant in gaining specialist knowledge. In many cases, the plot users could think that, having some experience in agriculture, it was no longer necessary to learn more and that attitude sometimes prevented them from being open to new knowledge and solutions concerning agricultural techniques. Similarly, the attitude of the public administration could affect the situation of allotment gardens. Sometimes public administrators believe that it is enough to establish an urban allotment garden and no further intervention is necessary trusting that gardeners use ecological practices that respect the health of people and the environment. However, it is essential to provide continuous and permanent training for the gardeners by professionals and agricultural educators. Such training should be coordinated by the public administration and integrated into the formation of plot users as it does not only solve daily problems of allotments but also connects the garden with the planet, the local with the global.

Apparently, the bank of autochthonous and ecological seeds has not been created in Baeza so far. What is more, there was no cooperation with any bank of indigenous and ecological seeds. If such cooperation existed the gardeners could gradually create their own bank of native seeds and as a result at the end of the harvest, they would be able to save the best seeds that could serve for future crops. Moreover, allotment gardens should be used as disseminators of environmental initiatives. As diffusers of environmental awareness they could be shown to schoolchildren in the municipality and even to other farmers. Unfortunately, allotment gardens in Baeza have not served this function so far.

\section{Acknowledgements}

Above all we would like to thank all the interviewees from the urban allotments in Baeza. We are particularly grateful to the allotment users Antonio Martinez Cabrero and Gregorio Ruiz Lopez for sharing their time, passion and ideas with us. We also express gratitude to the employees of the town hall in Baeza Rafael Poza responsible for infrastructure, Santiago Acero from technical department, Paulino Jimenez Jimenez responsible for the grocery market on behalf of the town hall, Adela Checa Godoy and Fernardo Rodriguez Higueras. Many thanks go to Maria Teresa Sanchez León, an entrepreneur functioning in the local grocery market. We also would like to thank the reviewers for their comments and suggestions regarding the earlier version of the article. Last but not least, we wish to express our gratefulness to Marta Kowalik and Stephany Bradley whose linguistic support was indispensable.

\section{References}

Anthopoulou T., 2012. Urban agriculture, social inclusion and sustainable cities: Case study of two municipal gardens in Northern Greece. Panteion University of Social and Political Science, Athens.

Ballesteros G., Fernández-Casadevante J.L., Morán N., 2014. Agricultura urbana: "A la huerta de la esquina". La Fertilidad de la tierra. Agricultura ecológica (58): 66-69.

Camps-Calvet M., Langemeyer J., Calvet-Mir L., Gómez-Baggethun E., March H., 2015. Sowing resilience and contestation in times of crises: The case of urban gardening movements in Barcelona. The Open Journal of Sociopolitical Studies 8(2): 417-442.

Calatayud S., 2005. La ciudad y la huerta. Historia agraria (35): 145-164.

Calvo García-Tornel F., 1982. Continuidad y cambio en la Huerta de Murcia. Edición de la Academia Alfonso X el Sabio Impreso en Sucesores de Nogués, Murcia.

Garnett T., 1996. Farming the city: The potential of urban agriculture. The Ecologist 26(6): 299-307.

Deelstra T., Girardet H., 2000. Urban agriculture and sustainable cities. In: Bakker N., Dubbeling M., Gündel S., Sabel-Koshella U., de Zeeuw H. (eds), Growing cities, growing food. Urban agriculture on the policy agenda. Zentralstelle für Ernährung und Landwirtschaft (ZEL). Feldafing, Germany: 43-66.

Fernández Casadevante Kois J.L., Morán N., 2015. Raíces en el asfalto: pasado, presente y futuro de la agricultura urbana. Libros en acción, Madrid.

Fernández J.L., Morán N., 2012. Cultivar la resiliencia. Los aportes de la agricultura urbana a las ciudades en transición. Papeles de relaciones ecosociales y cambio global (119): 131-143.

Hodgson K., Campbell M., Bailkey M., 2011. Urban agriculture: Growing healthy, sustainable places. American Planning Advisory Service, Chicago.

Hodgson K., Campbell M.C., Bailkey M., 2011. Investing in healthy, sustainable places through urban agriculture. Funders' Network for Smart Growth and Livable Communities: 1-15.

Francés M., Romero J. (eds), 2014. La Huerta de Valencia: un paisaje cultural con futuro incierto. València, Universitat de València: 210.

Junta de Andalucía, 2004. Estrategia Andaluza de Desarrollo Sostenible. Sevilla, Agenda 21 Andalucía: 1-113.

Junta de Andalucía, 2011. Estrategia Andaluza de Sostenibilidad Urbana, Sevilla: 1-69. 
McClintock N., 2010. Why farm the city? Theorizing urban agriculture through a lens of metabolic rift, Cambridge Journal of Regions, Economy and Society 3(2): 191-207.

McClintock N., 2018. Cultivating (a) sustainability capital: Urban agriculture, ecogentrification, and the uneven valorization of social reproduction. Annals of the American Association of Geographers 108(2): 579-590.

Maćkiewicz B., Puente R., Pawlak K., 2018. Reclaiming urban space: A study of community gardens in Poznań. Quaestiones Geographicae 37(4): 121-140.

Melo C., 2018. City and country relationships in the metropolitan area of València territorial policies for l'horta landscape. In: Baron N., Romero J. (eds), Cultura territorial e innovación social:i Hacia un nuevo modelo metropolitano en Europa del Sur? València, Universitat de València: 423-433.

Mougeot L., 2000. Urban agriculture: Definition, presence, potentials and risks. In: Bakker N., Dubbeling M., Guendel S., Sabel Koschella U., Zeeuw H. (eds), Growing cities, growing food, urban agriculture on the policy agenda. Hamburg, Feldafing, Germany: 1-42.

Mougeot L.J. (ed.), 2005. Agropolis: The social, political, and environmental dimensions of urban agriculture. Earthscan and the International Development Research Centre (IDRC), Ottawa.

Mougeot L.J., 2006. Growing better cities: Urban agriculture for sustainable development. Earthscan and the International Development Research Centre (IDRC), Ottawa.

Morán N., 2011. Huertos urbanos en tres ciudades europeas: Londres, Berlín, Madrid. Boletin CF+S (47/48): 5-124. http:// habitat.aq.upm.es/boletin/n47/anmor.html

Opitz I., Specht K., Berges R., Siebert R., Piorr A., 2016. Toward sustainability: Novelties, areas of learning and innovation in urban agriculture. Sustainability 8(4):356-373.

Pearson L., Pearson L., Pearson C., 2010. Sustainable urban agriculture: Stocktake and opportunities, International Journal of A gricultural Sustainability 8(1-2): 7-19.

Pourias J., 2015. Urban allotment gardens in the city in crisis. Insights from Sevilla (Spain). Short Report on the Short Term Scientific Mission. COST Action Urban Allotment Gardens in European Cities. www.urbanallotments.eu/ fileadmin/uag/media/STSM/rapport_final.pdf.

Puente R., 2010. Urbanizar con Huertos. Cimbra. 393: 24-29.

Puente R., 2011. De la Reivindicación a la Gestión en los Huertos Ecológicos de Sevilla. The Ecologist 1(46).

Puente R., 2012a. Los Huertos Urbanos de Sevilla: de la Tradición a la Novedad. Sevilla, Diputación De Sevilla.
Puente R., 2012b. La agricultura urbana como estrategia para la sostenibilidad en la ciudad contemporánea. In Sánchez Bravo Á.A. (ed.), Sostenibilidad ambiental urbana. ArCiBel, Sevilla: 483-513.

Puente R., 2013. Los huertos sociales en Andalucía. In: Turmo I.G. (ed.), Respuestas alimentarias a la crisis económica. Icaf, Sevilla.

Puente R., 2014. La agricultura urbana y periurbana en España. Desafíos actuales y tendencias. Revista AE. Agricultura y Ganadería Ecológica 16: 10-13.

Puente R., 2015. Les jardins urbains de Séville. L'engagement citadin face au désintérêt de l'Administration. Revue d'Ethnoecologie 8: 1-14. DOI : 10.4000/ethnoecologie.2317

Puente R., 2016. ¿Moda o necesidad? Los huertos urbanos en Andalucía. Revista Valor Ecológico 67: 34-35.

Purcell M., Tyman S.K., 2018. Cultivating food as a right to the city. In: Urban Gardening as Politics, Routledge: 62-81.

Segrelles J.A., 2015. Agricultura periurbana, parques naturales agrarios y mercados agropecuarios locales: una respuesta territorial y productiva a la subordinación del campo a la ciudad. Scripta Nova 19(502) 1:35.

Seguí A.E., Maćkiewicz B., Rosol M., 2017. From leisure to necessity: Urban allotments in Alicante Province, Spain in times of crisis. ACME: An International E-Journal for Critical Geographies 16(2): 277-304.

Smit J., Ratta A., Nasr J., 1996. Urban agriculture: Food, jobs and sustainable cities. Publication Series for Habitat II, Vol. I. United Nations Development Programme (UNDP), New York.

Tornaghi C., 2017. Urban agriculture in the food-disabling city: (Re)defining urban food justice, reimagining a politics of empowerment. Antipode 49(3): 781-801.

Turmo I.G., 2013. Respuestas alimentarias a la crisis económica. ICAF, Sevilla.

Van Tuijl E., Hospers G.J., Van Den Berg L., 2018. Opportunities and challenges of urban agriculture for sustainable city development. European Spatial Research and Policy 25: 5-22.

Verdaguer Viana-Cárdenas C., 2013. El campo y la ciudad, áreas de reencuentro. Hacia una Nueva Cultura del Territorio. Habitat y Sociedad 6: 11-40.

Walker S., 2016. Urban agriculture and the sustainability fix in Vancouver and Detroit. Urban Geography 37(2): 163182.

Wiskerke J.S., Viljoen A., 2012. Sustainable urban food provisioning: Challenges for scientists, policymakers, planners and designers. Wageningen Academic Publishers, Wageningen. 